\title{
Enhancing the Structural Performance of Column using GFRP Rebar and Hybrid Fiber
}

\author{
B. V. Manjari Blessing ${ }^{1}$ \\ Assistant Professor, \\ Department of Civil Engineering, \\ Anna University Regional Campus Coimbatore, \\ Coimbatore, India.
}

\author{
S. Vignesh ${ }^{2}$ \\ M.E- Structural Engineering, \\ Anna University Regional Campus Coimbatore, \\ Coimbatore, India.
}

\begin{abstract}
Glass fibre reinforced polymer (GFRP) rebars is a proven and successful alternative reinforcement that will give structures a longer service life as well as noncorrosive material properties. In this, present study an experimental study on columns with hybrid fibre and GFRP rebars was performed. Their performance was evaluated by comparison with a conventional steel reinforced column. Six hybrid columns with fibre and GFRP rebar and three conventional concrete steel reinforcement columns were casted and tested under different eccentric $(0,0)(0,25)(0,50)$ loadings. The fibres used were steel and glass fibres which improves the concrete strength property. Tests were done to check the load carrying capacity of columns for both axial and eccentric loads, deflection, and buckling nature of column. The GFRP rebars were able to withstand the peak concentric and eccentric loads without crushing and local buckling. Also after load removal, deflected GFRP column regained its original position and crack width also reduced. In steel reinforced column, steel rebar were yielded column and after load removal, no deflection regain and crack width reduction were found. The performance of HYFC rebar was $18 \%$ greater while considering to that of conventional concrete column.
\end{abstract}

Keywords - Elastic instability; GFRP; Hybrid fiber; load carrying capacity

\section{INTRODUCTION}

\section{A. General}

Columns are important structural members which carry the load from the beams and upper columns to transfer the ground through foundations. Column failure can cause elastic instability due to load carrying capacity of RCC columns reduced drastically for actual cross sectional area and percentage of reinforcement steel, crushing failure due to high axial load compared to cross sectional area of the members causes the RCC vertical member is crushed failure or material failure.

The most popular drawback for corrosion steel reinforcement due to aggressive environments, voids present in RCC member, coastal regions that cause weak tension strength of reinforcement hence failure of columns. Glass Fiber reinforced polymer (GFRP) rebar is a satisfying replacement or auxiliary for this condition because of its high tension strength (1600Mpa), noncorrosive characteristics.

ACI 440-1R-06 reported in the US typical uses GFRP rebar to constructed bridge deck, in 1997. FRP- composite material consisting of continuous fibers impregnated with a fiber binding polymer then moulded and hardened in the intended shape. Hybrid - a combination of two or more different fibers, such as carbon and glass or carbon and aramid, in to a structure In this present work was to investigate structural behavior of columns load vs deformational character, load carrying capacity for different eccentric conditions, spiffiness of the HYFRC column with GFRP compared the conventional steel reinforcement column. Hybrid fiber used to enhancing the concrete strength properties and prevent the crushing failure or material failure.

\section{B. Hybrid fibre}

Fibres are mostly used for special requirement only. the fibre used in concrete to increase the concrete strength properties and prevent the shrinkage crack, bleeding of water etc. different type of fibre such as glass fibre, coconut fibre, glass fibre, polypropylene. A composite can be termed as hybrid, if two or more types of fibres are rationally combined in a common matrix to produce a composite that drives benefits from each of the individual's fibres and exhibits a synergetic response.

\section{GFRP rebar}

Glass fibre reinforced polymer (GFRP) rebar is sold bar which contain of thinnest glass fibre embedded in a polymeric resin matrix and additives. The major cause of deterioration among reinforced concrete structures is corrosion of the reinforcing steel. Among others, one viable option is to reinforce concrete with glass fiber-reinforced polymer (GFRP) bars, a non-corrosive material.

GFRP reinforcing bars are made primarily of glass fibers. Being non-corrosive, GFRP bars can help extend the lifecycle of reinforced concrete structures substantially, as well as reduce their maintenance, repair, and replacement costs. While GFRP is becoming a viable reinforcement alternative, it presents design challenges which are different than those in the design of conventional steel reinforced concrete.

\section{MATERIAL USED}

\section{A. Cement}

Ordinary Portland cement conform to IS 10262-2009 JSW cement 53 grade produced from single source was used 


\begin{tabular}{|c|c|}
\hline Properties & Specifications \\
\hline Specific gravity & 3.15 \\
\hline grade & 53 \\
\hline
\end{tabular}

B. Fine aggregate

Locally available river sand was used as fine aggregate which passes through $4.75 \mathrm{~mm}$ sieve as per IS 383-1978

\begin{tabular}{|l|l|}
\multicolumn{1}{c|}{ TABLE 2 PROPERTIES OF FINE AGGREGATE } \\
\hline \multicolumn{1}{|c|}{ Properties } & \multicolumn{1}{c|}{ Specifications } \\
\hline Specific gravity & 2.67 \\
\hline Fineness modulus & 2.8 \\
\hline
\end{tabular}

\section{C. coarse aggregate}

Locally available coarse aggregate was used as coarse aggregate which passes through $20 \mathrm{~mm}$ to retain $12.5 \mathrm{~mm}$ sieve as per IS 383-1978. The specific gravity of the coarse aggregate is 2.74 .

D. water

Potable water which is available in laboratory is used for casting and curing of specimen as per IS 456-2000. W/C .45 was in mix.

E. Steel fibre

Defined as short, discrete length of steel fibres with an aspect ratio 20 to 100 with different types of steel fibres is used for concrete reinforcement. Round fibres are the most common type and their diameter ranges from 0.25 to $0.75 \mathrm{~mm}$. Rectangular steel fibres are usually $0.25 \mathrm{~mm}$ thick.

\begin{tabular}{|l|l|}
\multicolumn{1}{|c|}{ TABLE 3 PROPERTIES OF STEEL FIBRE } \\
\hline \multicolumn{1}{|c|}{ Properties } & \multicolumn{1}{c|}{ Specifications } \\
\hline Type of steel fibre & Crimped \\
\hline Length & $50 \mathrm{~mm}$ \\
\hline Diameter of fibre & $0.5 \mathrm{~mm}$ \\
\hline Aspect ratio & 100 \\
\hline Percentage & $0.75 \%$ (volume of cement) \\
\hline
\end{tabular}

\section{F. Glass fibre}

Glass fibre is a material consisting of numerous extremely fine fibres of glass. Glass fibre thinnest fibres are the strongest because the thinner fibres are more ductility.

TABLE 4 PROPERTIES OF GLASS FIBRE

\begin{tabular}{|l|l|}
\hline \multicolumn{1}{|c|}{ Properties } & \multicolumn{1}{c|}{ Specifications } \\
\hline Type of Glass fibre & Alkali resistant \\
\hline Length & $12 \mathrm{~mm}$ \\
\hline Diameter of fibre & $0.05 \mathrm{~mm}$ \\
\hline Aspect ratio & 240 \\
\hline Percentage & $0.75 \%$ (volume of cement) \\
\hline
\end{tabular}

\section{G. GFRP rebars}

GFRP- Fibreglass and composite material consisting of continuous fibres impregnated with a fibre binding polymer then moulded and hardened in the intended shape. Non corrodible, high tensile strength, low weight compare to steel. Different diameter is available $6 \mathrm{~mm}, 8 \mathrm{~mm}, 10 \mathrm{~mm}, 12 \mathrm{~mm}$, and $16 \mathrm{~mm}$.

\begin{tabular}{|l|l|}
\hline \multicolumn{1}{|c|}{ Properties } & \multicolumn{1}{c|}{ TABLE 5 PROPERTIES OF GFRP } \\
\hline Tensile strength & 483 to $1600 \mathrm{Mpa}$ \\
\hline Modulus of elasticity & $51.0 \mathrm{Gpa}$ \\
\hline Density & 1.25 to $2.1 \mathrm{~g} / \mathrm{cm}^{3}$ \\
\hline
\end{tabular}

TABLE 6 MECHANICAL PROPERTIES OF GFRP

\begin{tabular}{|l|l|l|l|l|}
\hline $\begin{array}{c}\text { Diameter } \\
(\mathbf{m m})\end{array}$ & \multicolumn{1}{|c|}{ Area $\left(\mathbf{m m}^{2}\right)$} & Density $\left(\mathbf{g} / \mathbf{c m}^{\mathbf{3}}\right)$ & $\begin{array}{c}\text { Tensile strength } \\
(\mathbf{M p a})\end{array}$ & $\begin{array}{c}\text { Modulus of } \\
\text { elasticity } \\
(\mathbf{G p a})\end{array}$ \\
\hline 6 & 28.27 & 1.25 & 1600 & 51.0 \\
\hline 8 & 50.26 & 1.25 & 1600 & 51.0 \\
\hline 10 & 78.5 & 1.25 & 1500 & 51.0 \\
\hline 12 & 113.09 & 1.25 & 1350 & 51.0 \\
\hline
\end{tabular}

\section{H. Concrete mix proportion}

Mix proportion of $\mathrm{M}_{35}$ grade concrete was designed as per IS 10262-2009 and IS 456-2000. 


\begin{tabular}{|l|ll|}
\multicolumn{1}{|c|}{ TABLE 7: MIX PROPORTION } \\
\begin{tabular}{|l|ll|}
\hline \multicolumn{1}{|c|}{ Properties } & \multicolumn{1}{c|}{ Specifications } \\
\hline Grade & $\mathrm{M}_{35}$ & \\
\hline Ratio & $1: 1.6: 2.5$ & \\
\hline Water cement ratio & 0.45 & \\
\hline
\end{tabular}
\end{tabular}

\section{TEST PROGRAM}

The test program consisted of 9 concrete columns measuring $150 \mathrm{~mm} \times 150 \mathrm{~mm} \times 1000 \mathrm{~mm}$ cross section, the test column could be specified as a short column because the slenderness ratio $(\mathrm{L} / d)$ of the specimens was less than to 12 , that is, less than 22 based on ACI 318-14 [24]. The tested specimens were divided into three groups, as shown in Table 1. Each group consisted of two concrete columns with the same reinforcement details but tested under different eccentricity conditions of 0,25 , and $50 \mathrm{~mm}$ ( equal tov $(0,0),(0,25)$, and $(1,50)$, respectively). The specimens were identified on the basis of the longitudinal and tie reinforcement material (steel or GFRP), diameter of the longitudinal bar, tie spacing, and eccentricity amount of the applied load. For example, specimen G10-T150-E0.0 is reinforced with GFRP bars and ties, four 10 mm diameter bars were used as longitudinal reinforcement, tie spacing was $150 \mathrm{~mm}$, and it was tested under concentric load. the first group (S10-T150, reference specimens) consisted of three concrete columns reinforced with four $\varnothing 10$ longitudinal steel bars and $\emptyset 6$ steel ties placed at a spacing of $150 \mathrm{~mm}$. the columns in the three other groups were reinforced with GFRP bars and tie. The dial gauge was positioned at mid height to measure the lateral deflection of the column during the loading stage.

TABLE 8 DETAILS OF TESTED SPECIMEN

\begin{tabular}{|c|c|c|c|c|}
\hline S. no & Specimen & Type of bar & Main bar & Lateral tie \\
\hline \multirow[t]{3}{*}{1.} & S10-T150-E0,0 & \multirow{3}{*}{ STEEL } & $4 \mathrm{Y}-10$ & Y6 AT 150mm \\
\hline & S10-T150-E0,25 & & $4 \mathrm{Y}-10$ & Y6 AT $150 \mathrm{~mm}$ \\
\hline & S10-T150-E0,50 & & $4 Y-10$ & Y6 AT $150 \mathrm{~mm}$ \\
\hline \multirow{3}{*}{2.} & G10-T150-E0,0 & \multirow{3}{*}{ GFRP } & $4 \mathrm{Y}-10$ & Y6 AT $150 \mathrm{~mm}$ \\
\hline & G10-T150-E0,25 & & $4 \mathrm{Y}-10$ & Y6 AT $150 \mathrm{~mm}$ \\
\hline & G10-T150-E0,50 & & $4 Y-10$ & Y6 AT $150 \mathrm{~mm}$ \\
\hline
\end{tabular}

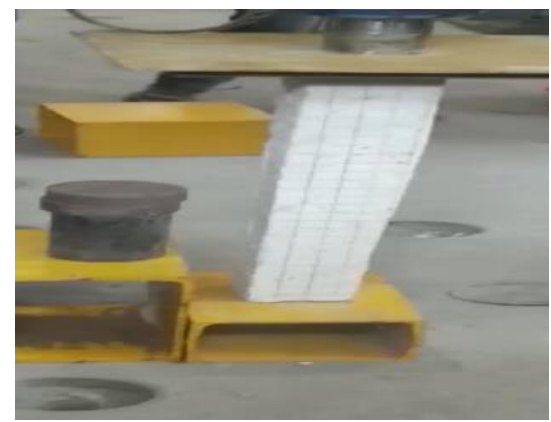

Fig: 1 Column test setup

\section{A. Cube test result}

\section{TEST RESULTS}

Compressive strength is the maximum compressive stress that, under a gradually applied load, given solid material can sustain without fracture. Compressive strength is calculated by dividing the maximum load by the original cross section area of the specimen in compression test. Cube test result mentioned below in table 9 ( 7 days test)

TABLE 9 TEST RESULTS OF COMPRESSIVE STRENGTH OF CONCRETE

\begin{tabular}{|c|c|c|c|c|c|c|}
\hline S.no & Specimen & $\begin{array}{c}\text { Dimension } \\
\text { (mm) }\end{array}$ & $\begin{array}{l}\text { Initial load } \\
\quad(\mathbf{k n})\end{array}$ & $\begin{array}{l}\text { Final load } \\
\text { (kn) }\end{array}$ & $\begin{array}{c}\text { Compressive } \\
\text { strength }\left(\mathbf{n} / \mathbf{m m}^{2}\right)\end{array}$ & $\begin{array}{l}\text { Percentage of strength } \\
\text { compare hyfrc to cc }\end{array}$ \\
\hline 1. & $\mathrm{CC}$ & 150x150 & 571 & 621 & 27.62 & \multirow{5}{*}{$\begin{array}{l}8 \% \text { Increase } \\
17 \% \text { Increase } \\
24 \% \text { Increase } \\
20 \% \text { Increase }\end{array}$} \\
\hline 2. & $\begin{array}{l}\text { HYFRC } \\
0.9 \%\end{array}$ & $150 \times 150$ & 629 & 670 & 29.77 & \\
\hline 3. & $\begin{array}{l}\text { HYFRC } \\
1.1 \%\end{array}$ & $150 \times 150$ & 683 & 726 & 32.26 & \\
\hline 4. & $\begin{array}{l}\text { HYFRC } \\
1.3 \%\end{array}$ & $150 \times 150$ & 712 & 770 & 34.22 & \\
\hline 5. & $\begin{array}{l}\text { HYFRC } \\
1.5 \%\end{array}$ & $150 \times 150$ & 706 & 738 & 32.82 & \\
\hline
\end{tabular}




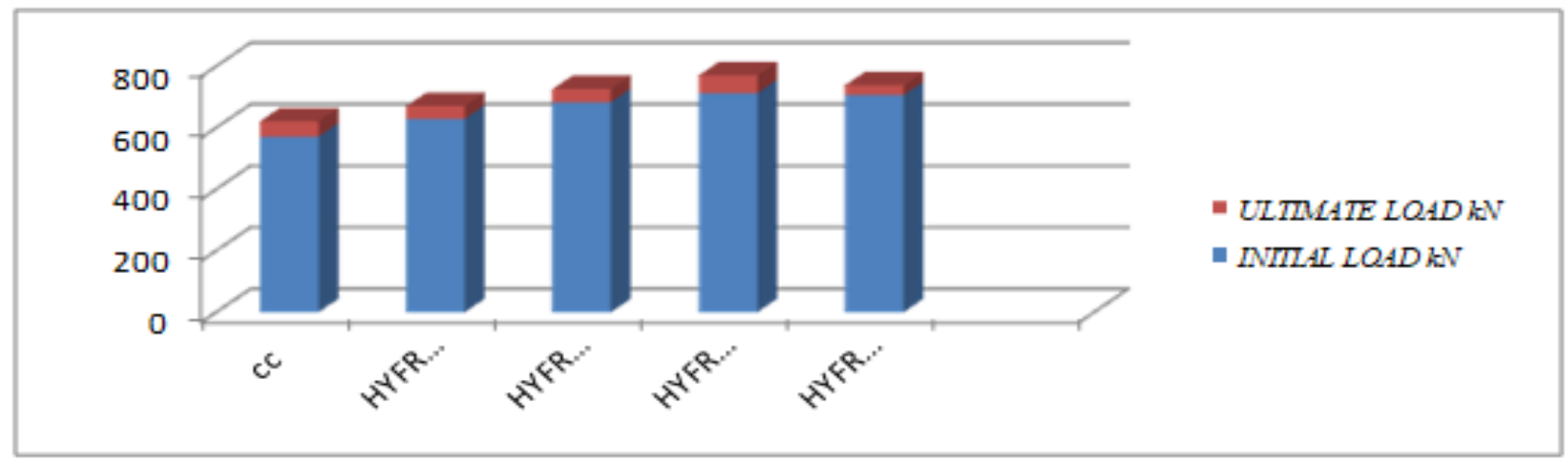

Fig: 2 cube test result

B. Experimental test results on the column load carrying capacity

The section discussion for test results of steel reinforcement RCC column and HYFC with GFRP rebar RCC column. All specimen were tested under the different eccentric $(0,0)(0,25)(0,50)$ load condition they failed and their reached maximum load carrying capacity. The moment and stiffness are finding as the maximum load vs horizontal deflection at maximum load. The results are show table: 10 .

TABLE 10 RESULTS FOR TESTED SPECIMEN

\begin{tabular}{|c|l|l|l|l|l|}
\hline S. no & \multicolumn{1}{|c|}{ Specimen } & \multicolumn{1}{|c|}{$\mathbf{E}_{\min }(\mathbf{m m})$} & \multicolumn{1}{|c|}{$\mathbf{P}_{\text {Max }}(\mathbf{K N})$} & \multicolumn{1}{|c|}{$\mathbf{Y}_{\text {Max }}(\mathbf{m m})$} & $\mathbf{M}_{\text {Max }}(\mathbf{K N} . \mathbf{m})$ \\
\hline \multirow{2}{*}{1.} & S10-T150-E0,0 & 0 & 179 & 1.30 & 0.234 \\
\cline { 2 - 6 } & S10-T150-E0,25 & 25 & 126 & 8.50 & 1.077 \\
\cline { 2 - 6 } & S10-T150-E0,50 & 50 & 94 & 12.7 & 1.238 \\
\hline \multirow{3}{*}{2.} & G10-T150-E0,0 & 0 & 210 & 1.45 & 0.30 \\
\cline { 2 - 6 } & G10-T150-E0,25 & 25 & 137 & 11.45 & 1.56 \\
\cline { 2 - 6 } & G10-T150-E0,50 & 50 & 85 & 16.7 & 1.42 \\
\hline
\end{tabular}

B.1 Conventional column reinforced with steel bar

For column specimen 1:

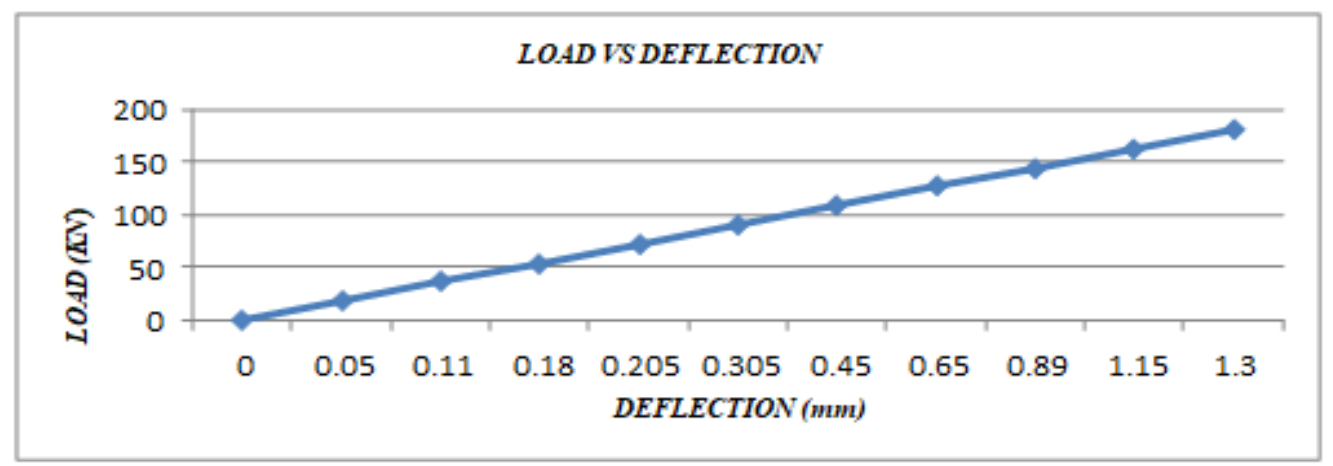

Fig: 3 Load vs Deflection S10-T150-E0, 0

For column specimen 2:

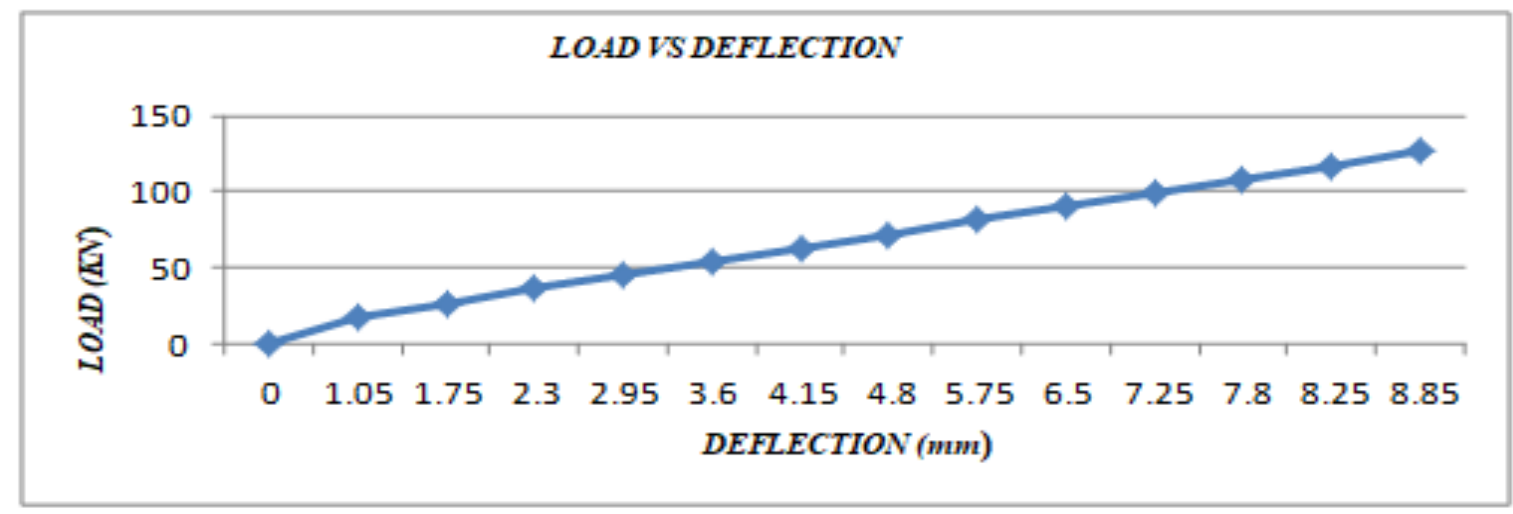

Fig: 4 Load vs Deflection S10-T150-E 0, 25 
For column specimen 3:

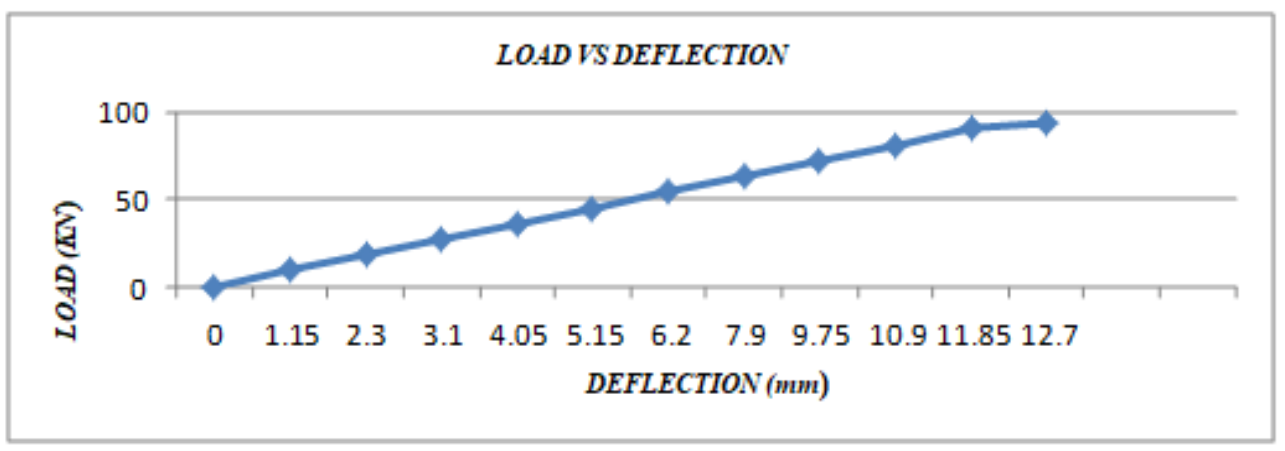

Fig: 5 Load vs Deflection S10-T150-E 0, 50

B.2 Hyfrc column reinforced with gfrp rebar eccentricity $(0,0)$

For column specimen 1:

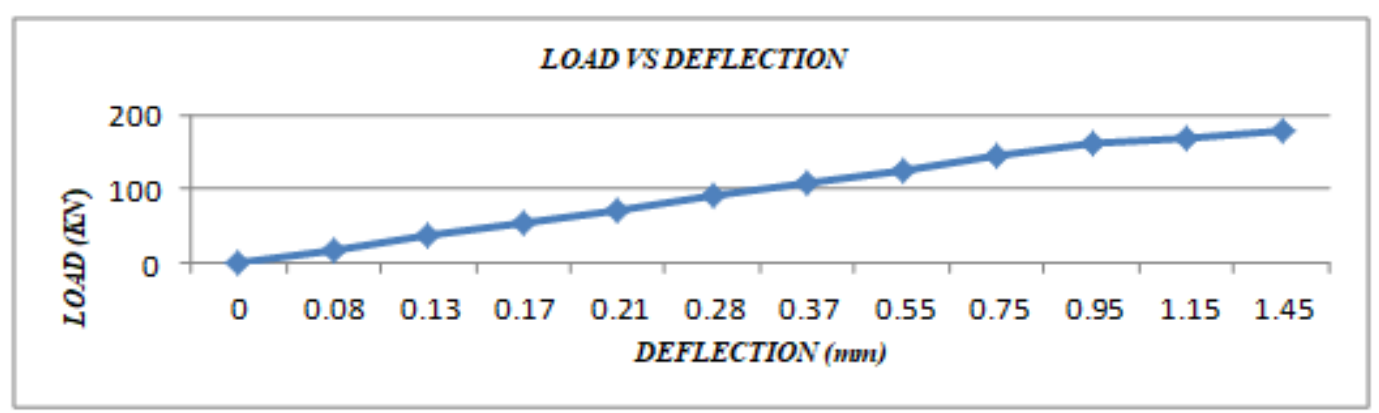

For column specimen 2:

Fig: 6 Load vs Deflection G10-T150-E 0,0

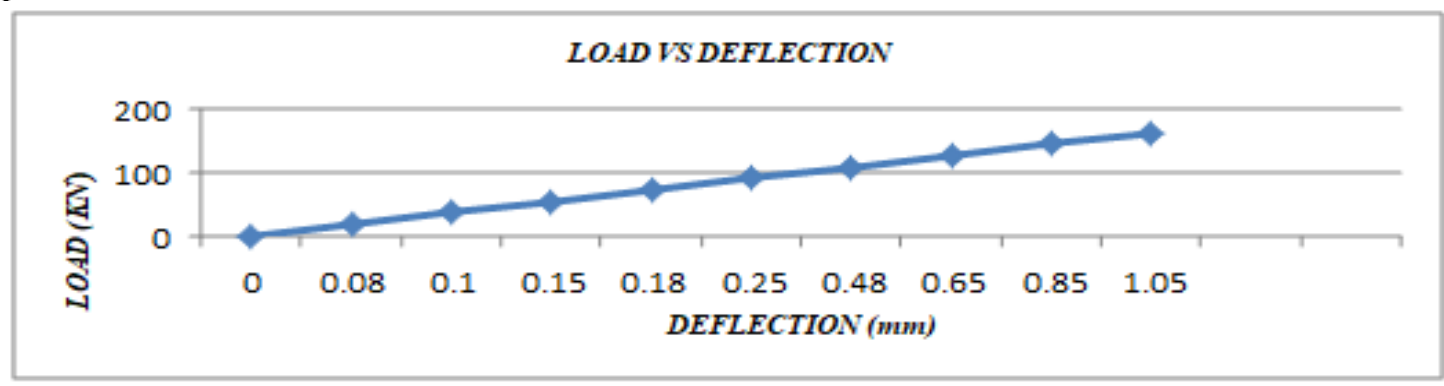

Fig: 7 Load vs Deflection G10-T150-E 0, 0

B.3 Hyfrc column reinforced with gfrp rebar eccentricity $(0,25)$

For column specimen 1:

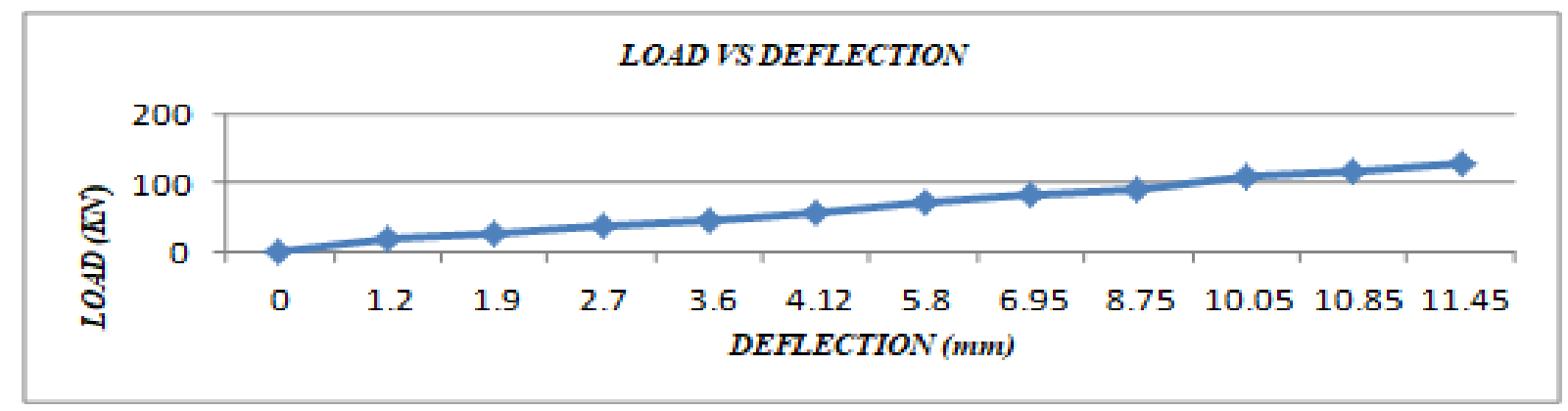

Fig: 8 Load vs Deflection G10-T150-E 0, 25 
For column specimen 2:

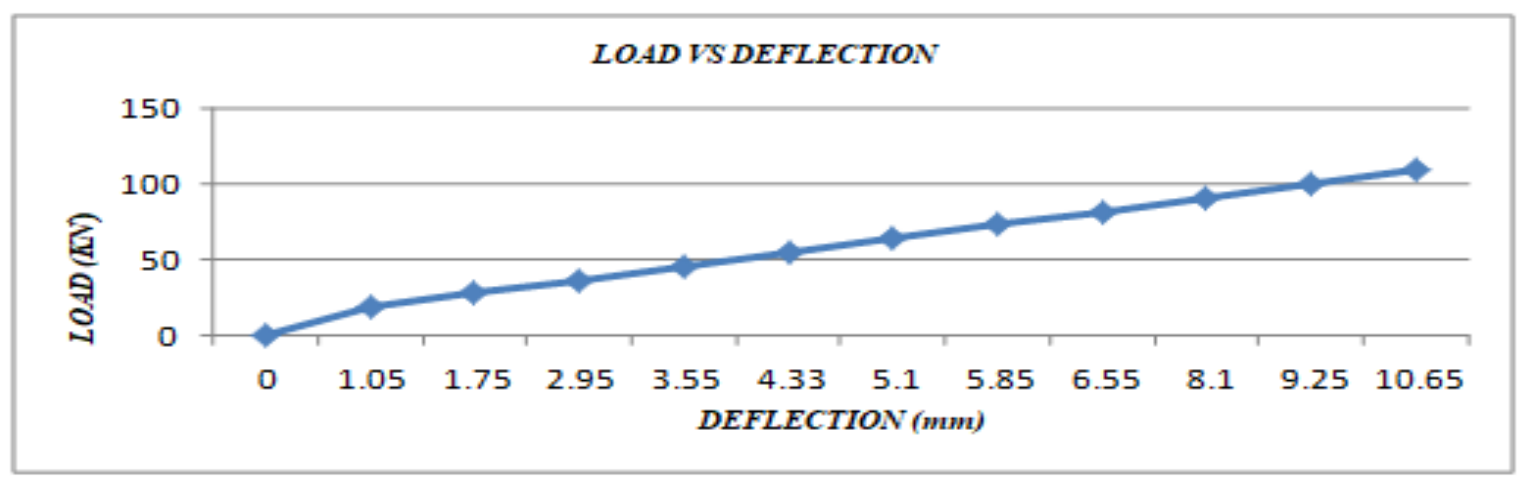

Fig: 9 Load vs Deflection G10-T150-E 0, 25

B.4 Hyfrc column reinforced with gfrp rebar eccentricity $(0,50)$

For column specimen 1:

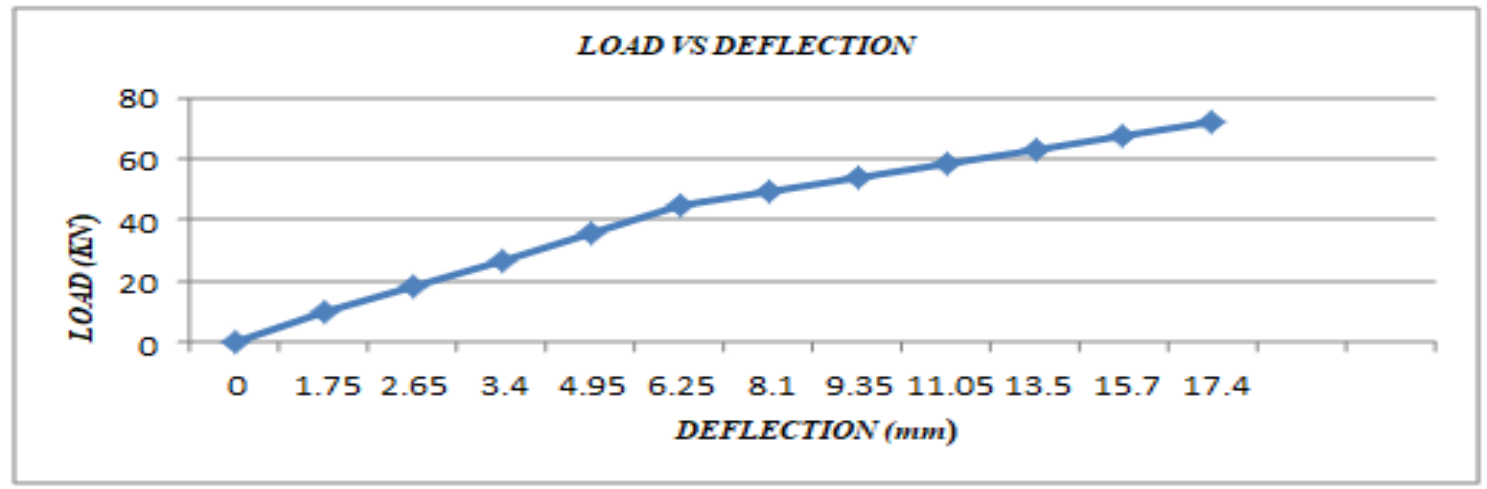

For column specimen 2:

Fig: 10 Load vs Deflection G10-T150-E 0, 50

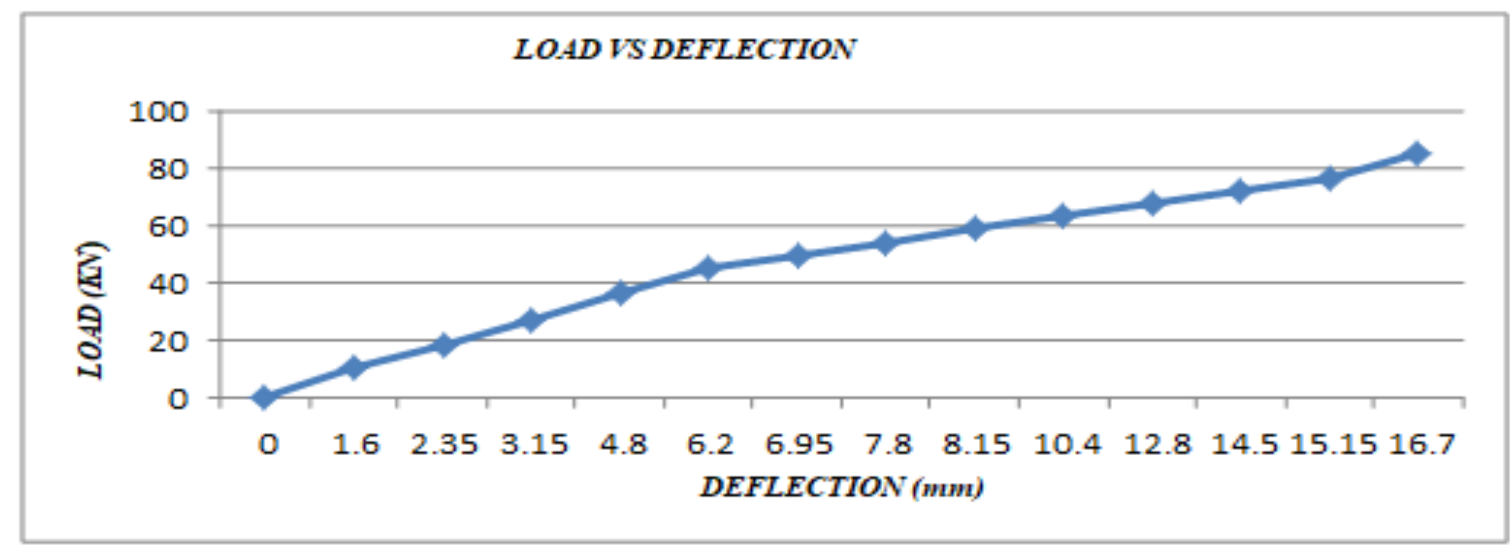

Fig: 11 Load vs Deflection G10-T150-E 0, 50

\section{Load vs Moment characteristics}

Maximum moment was calculated as the maximum load multiplied by the summation of initial eccentricity and lateral displacement at maximum load. 


\section{C.1 Conventional column reinforced with steel bar}

For beam specimen 1:

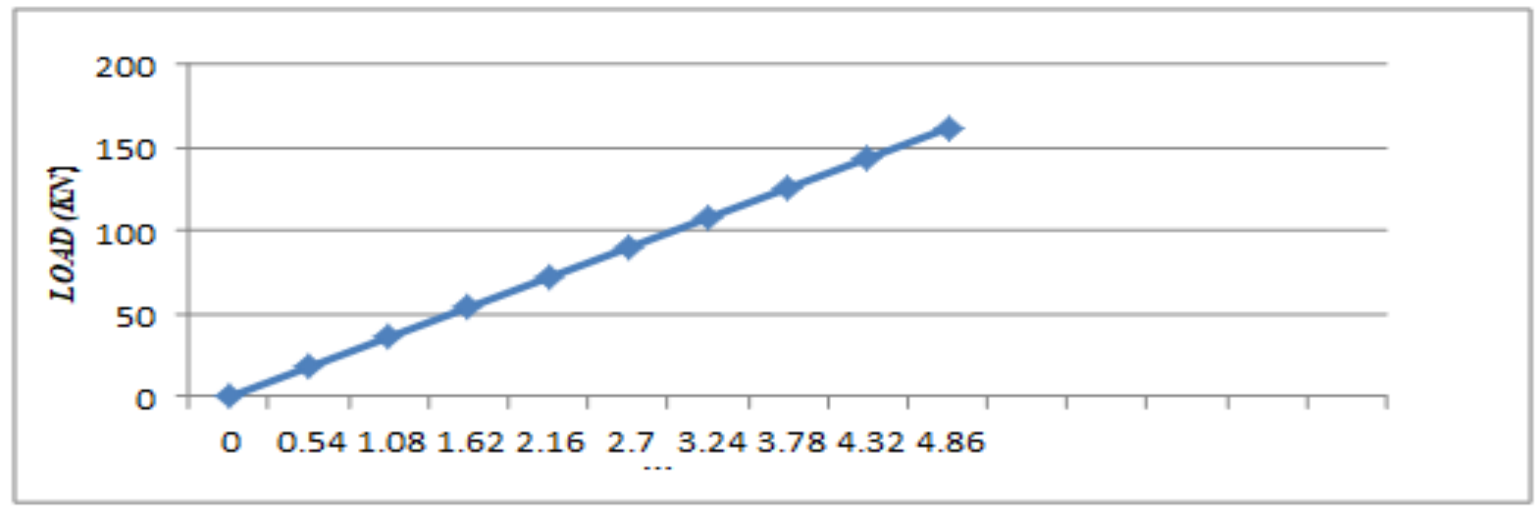

Fig: 12 Load vs M̈oment - S10-T150-E0, 0

For column specimen 2:

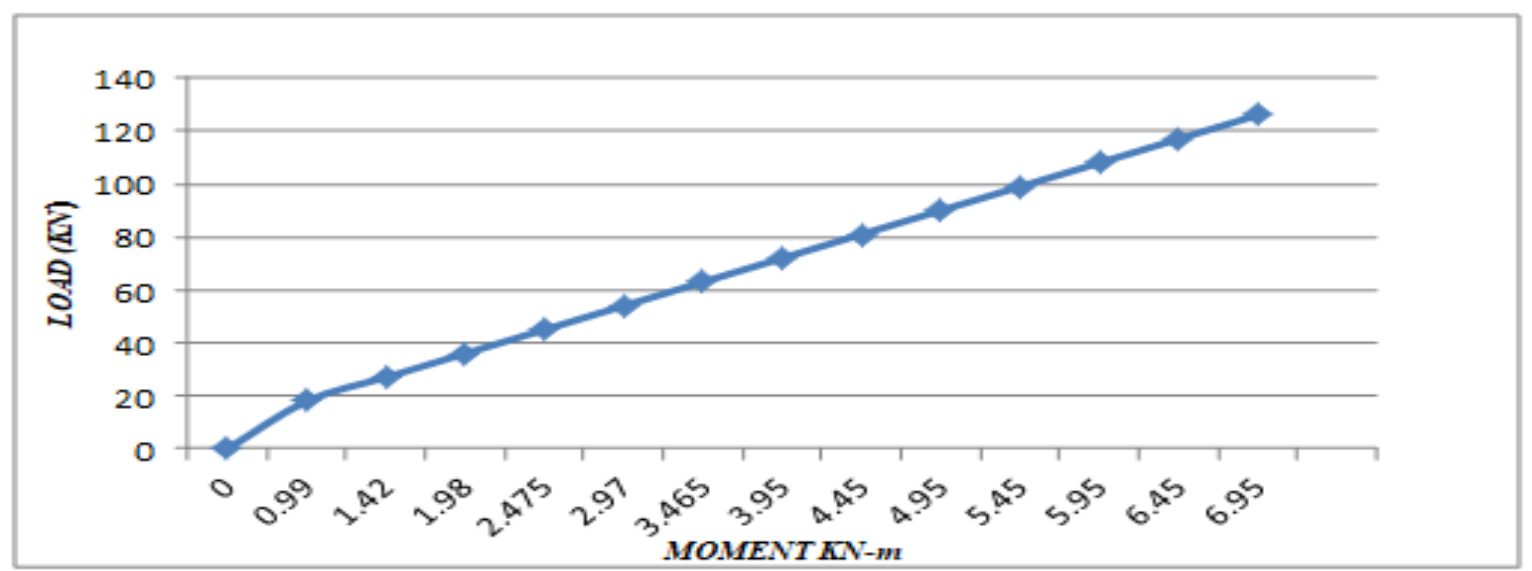

Fig: 13 Load vs Moment - S10-T150-E0, 25

For column specimen 3:

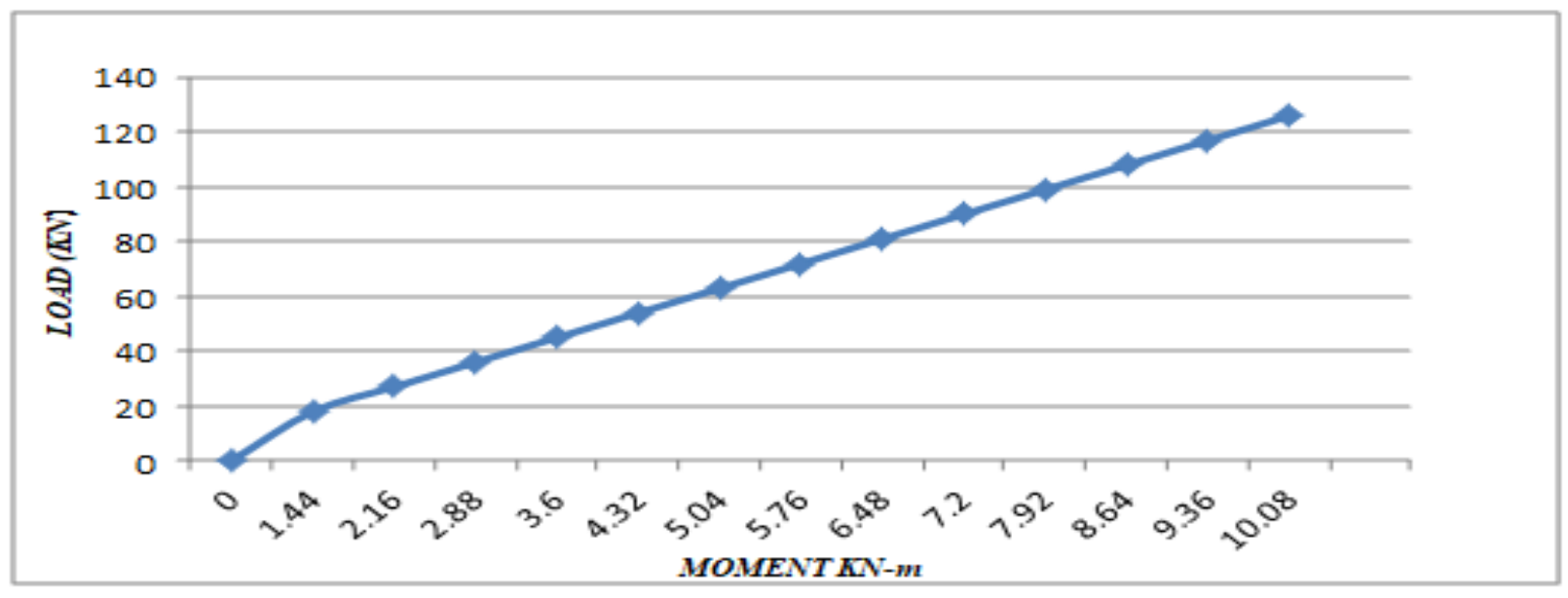

Fig: 14 Load vs Moment - S10-T150-E0, 50 
C.2 Hyfrc column reinforced with gfrp rebar eccentricity $(0,0)$

For column specimen 1:

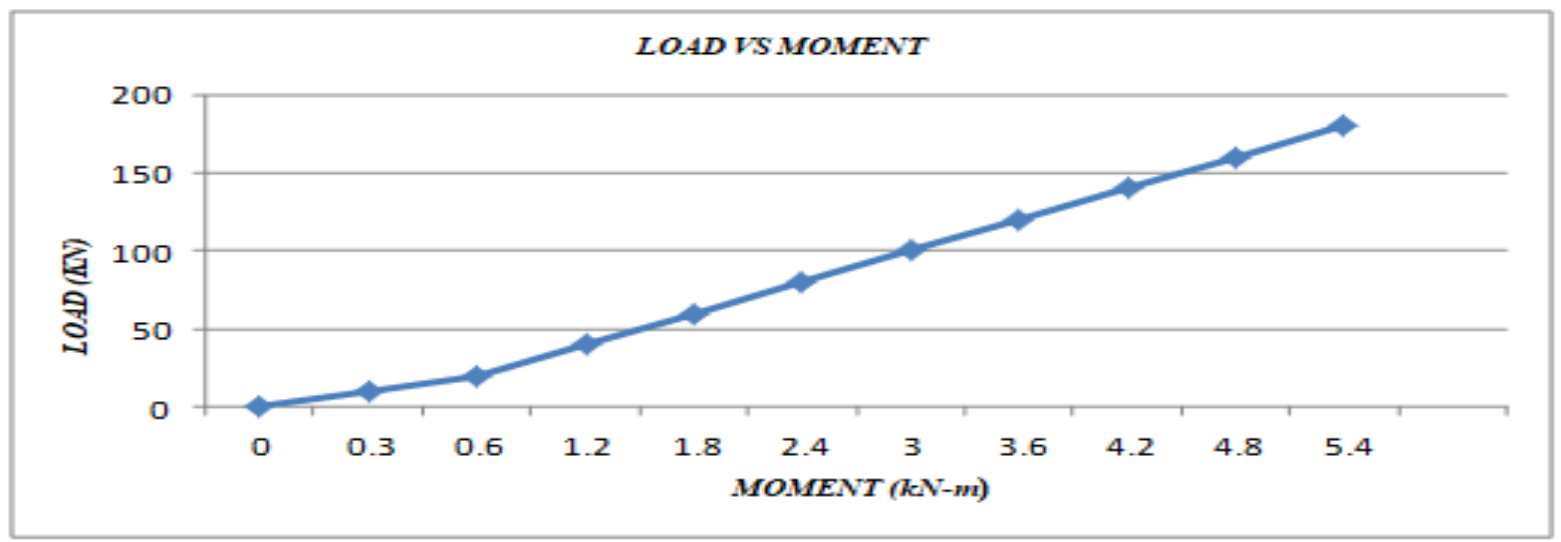

Fig: 15 Load vs Moment - G10-T150-E0, 0-1

For column specimen 2:

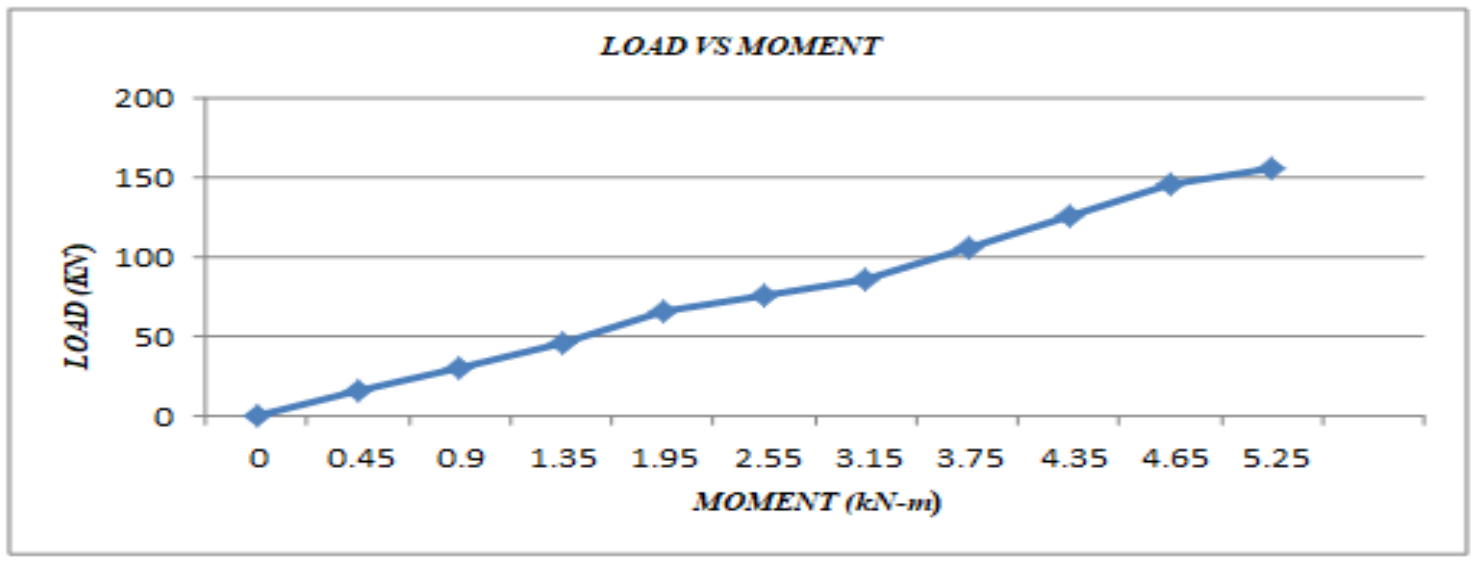

Fig: 16 Load vs Moment - G10-T150-E0, 0-2

C.3 Hyfrc column reinforced with gfrp rebar eccentricity $(0,25)$

For column specimen 1:

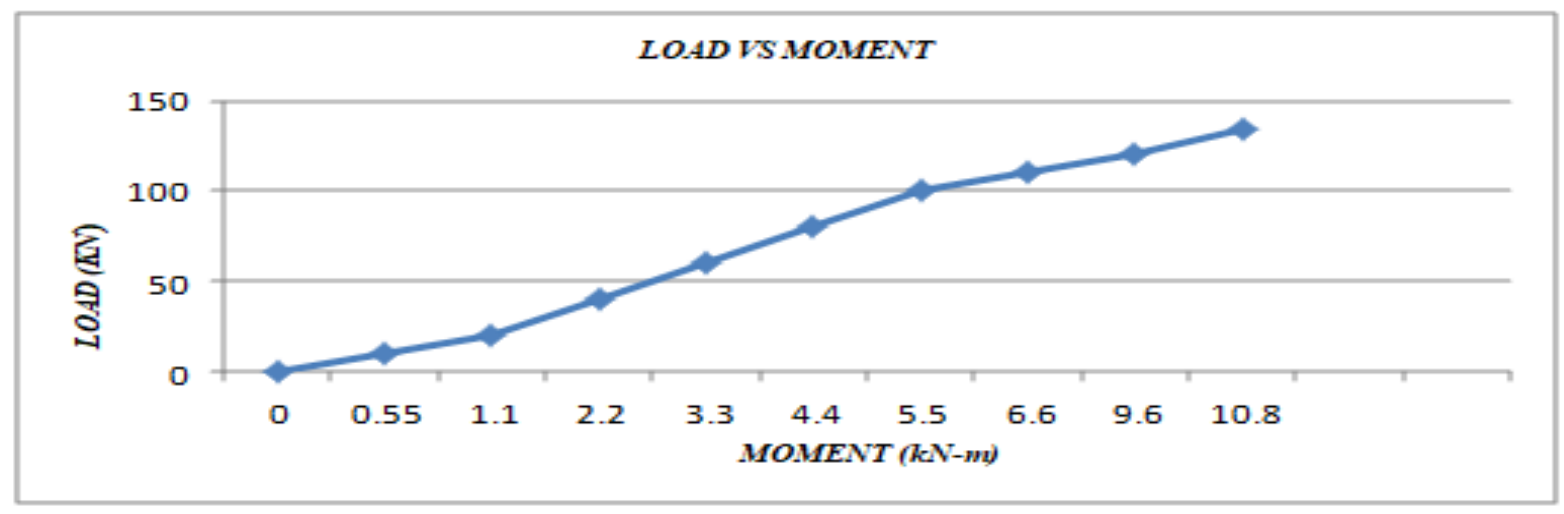

Fig: 17 Load vs Moment - G10-T150-E0, 25-1 
For column specimen 2:

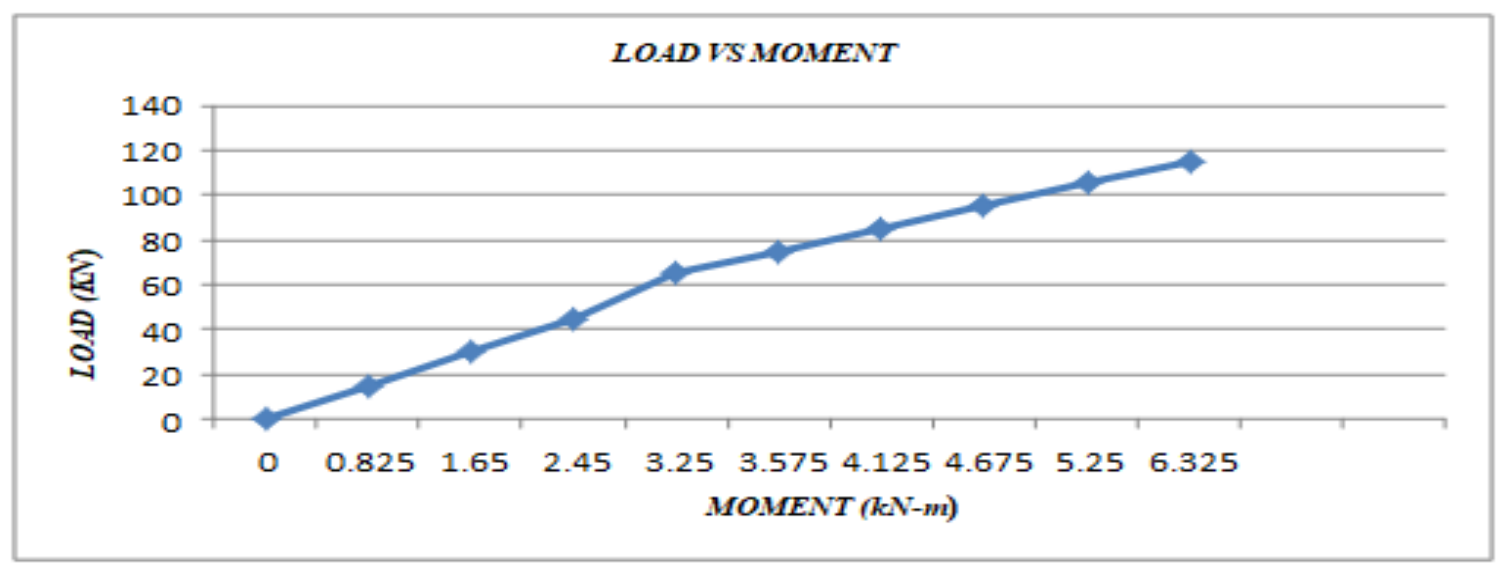

Fig: 18 Load vs Moment - G10-T150-E0, 25-2

C.4 Hyfrc column reinforced with gfrp rebar eccentricity $(0,50)$

For column specimen 1:

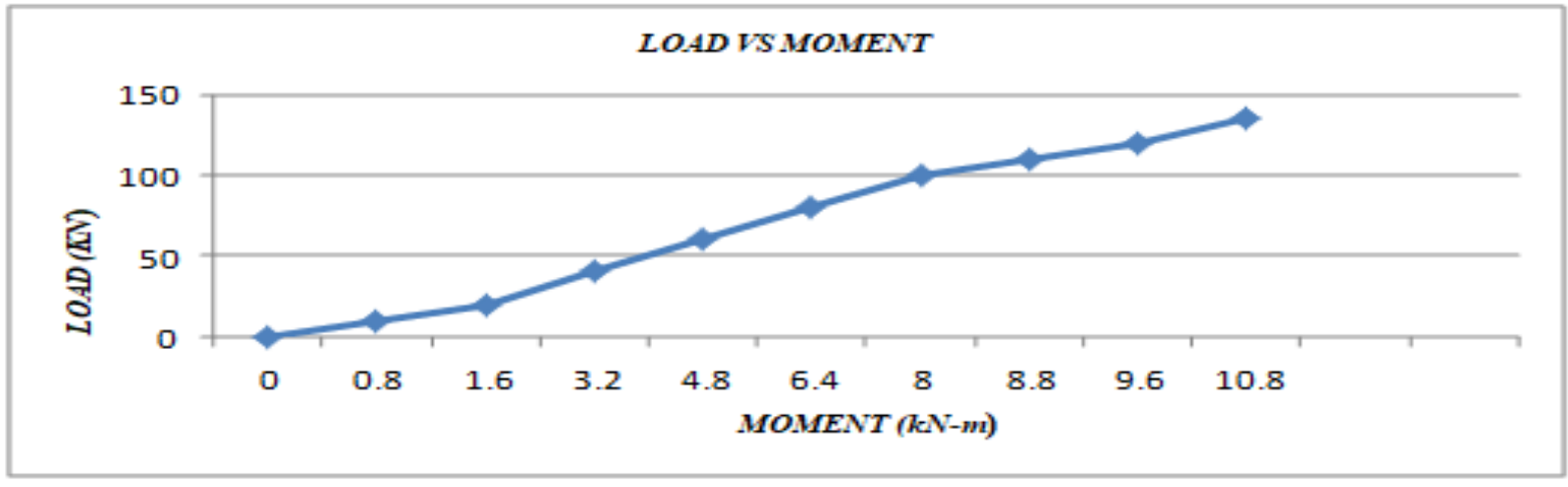

For column specimen 2:

Fig: 19 Load vs Moment - G10-T150-E0, 50-1

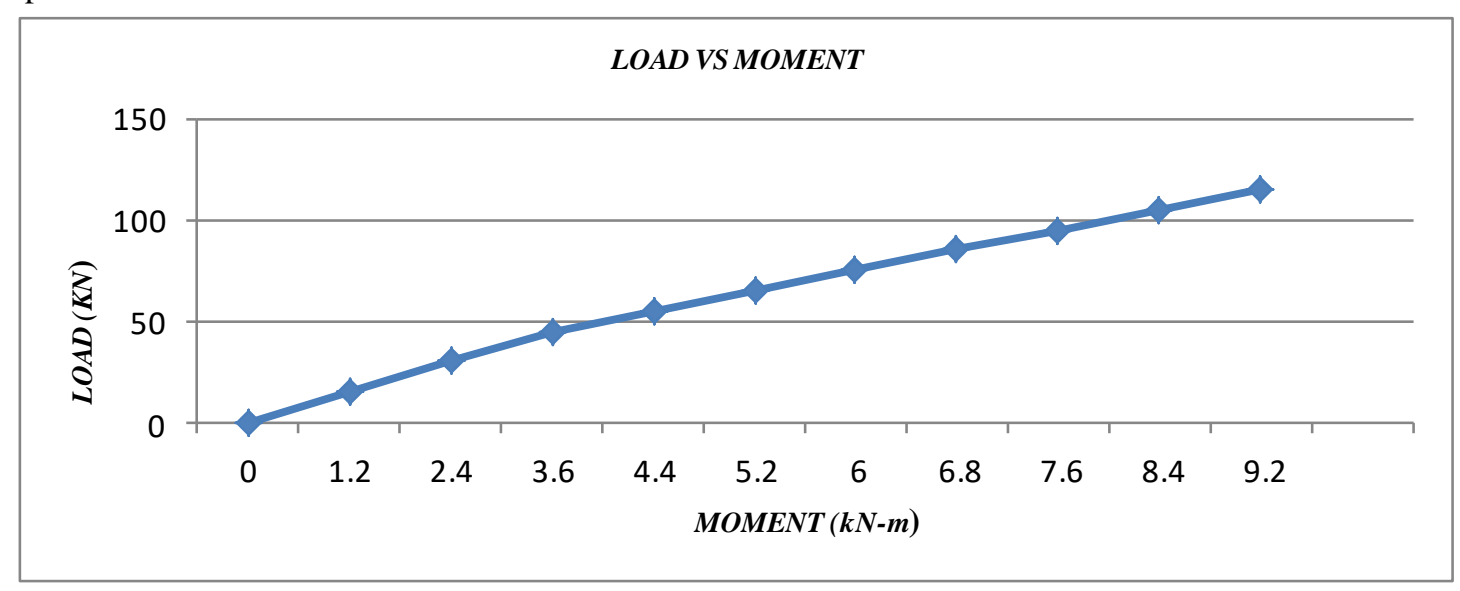

Fig: 20 Load vs Moment - G10-T150-E0, 50-2 
D. Compare load carrying capacity of hyfrc column reinforced with gfrp rebar to conventional column

TABLE 11 TEST RESULT OF LOAD CARRYING CAPACITY

\begin{tabular}{|l|l|l|l|l|}
\hline \multirow{2}{*}{ S. no } & Specimen & $\begin{array}{l}\text { Max } \\
\text { load (kn) }\end{array}$ & \multicolumn{1}{c|}{$\begin{array}{c}\text { Avg } \\
\text { load(kn) }\end{array}$} & $\begin{array}{c}\text { Max } \\
\boldsymbol{\delta} \text { mm }\end{array}$ \\
\hline \multirow{3}{*}{1.} & S10-T150-E0,0 & 179 & 179 & 1.30 \\
\cline { 2 - 5 } & G10-T150-E0,0 & 210 & 191.5 & 1.45 \\
\cline { 2 - 5 } & G10-T150-E0,0 & 173 & 126 & 8.85 \\
\cline { 2 - 5 } 2. & S10-T150-E0,25 & 126 & 124.5 & 12.25 \\
\cline { 2 - 5 } & G10-T150-E0,25 & 135 & 94 & 11.85 \\
\cline { 2 - 5 } 3. & G10-T150-E0,25 & 117 & & 18.1 \\
\hline
\end{tabular}

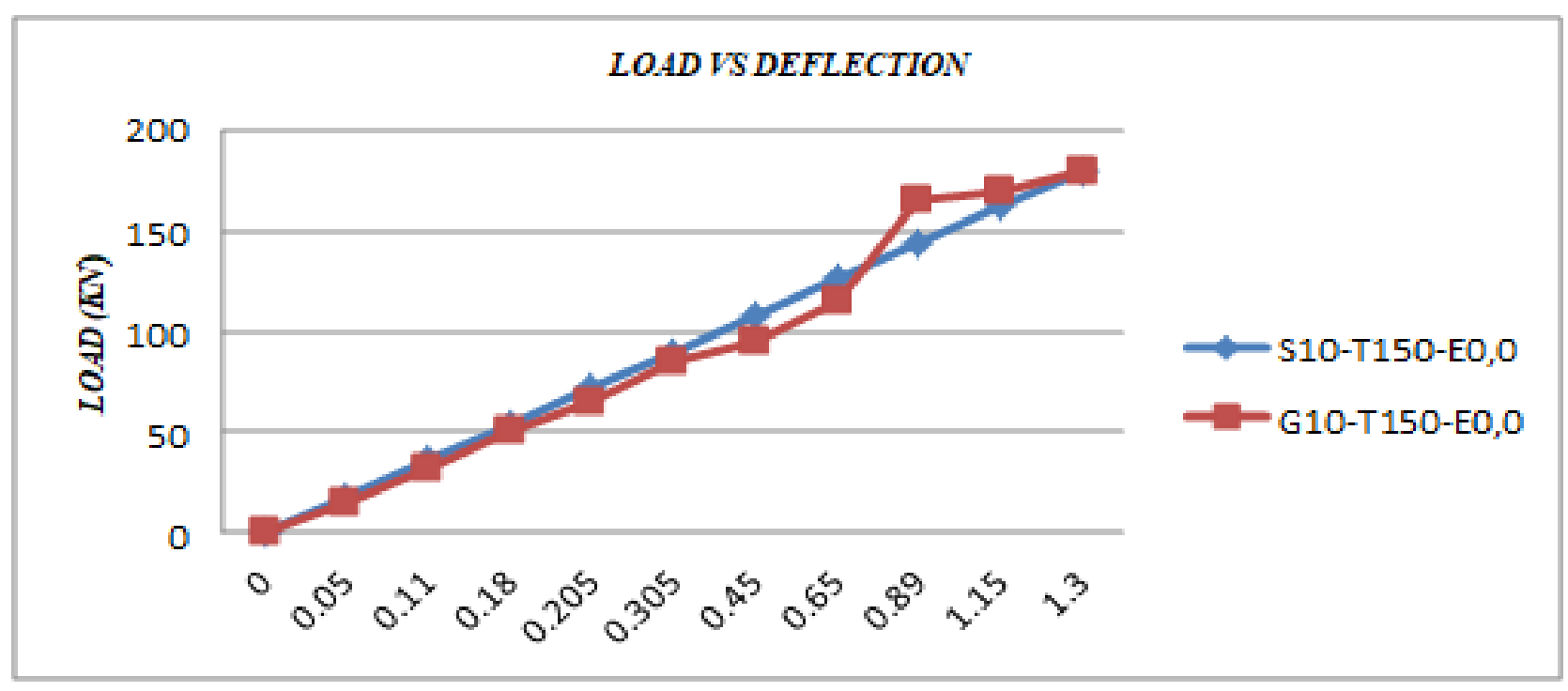

Fig: 21 Load vs Deflection - G10-T150-E0, 0 AND S10-T150-E0, 0

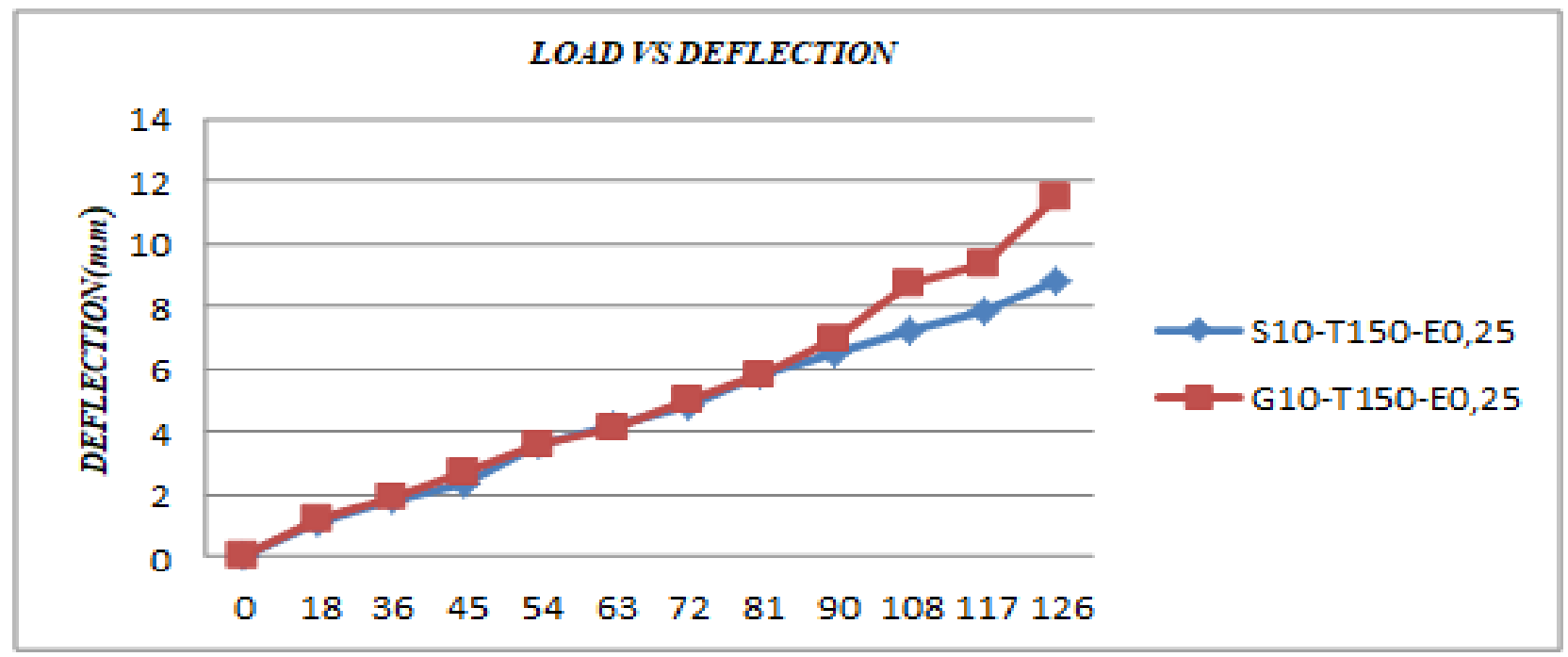

Fig: 22 Load vs Deflection - G10-T150-E0, 25 AND S10-T150-E0, 25 


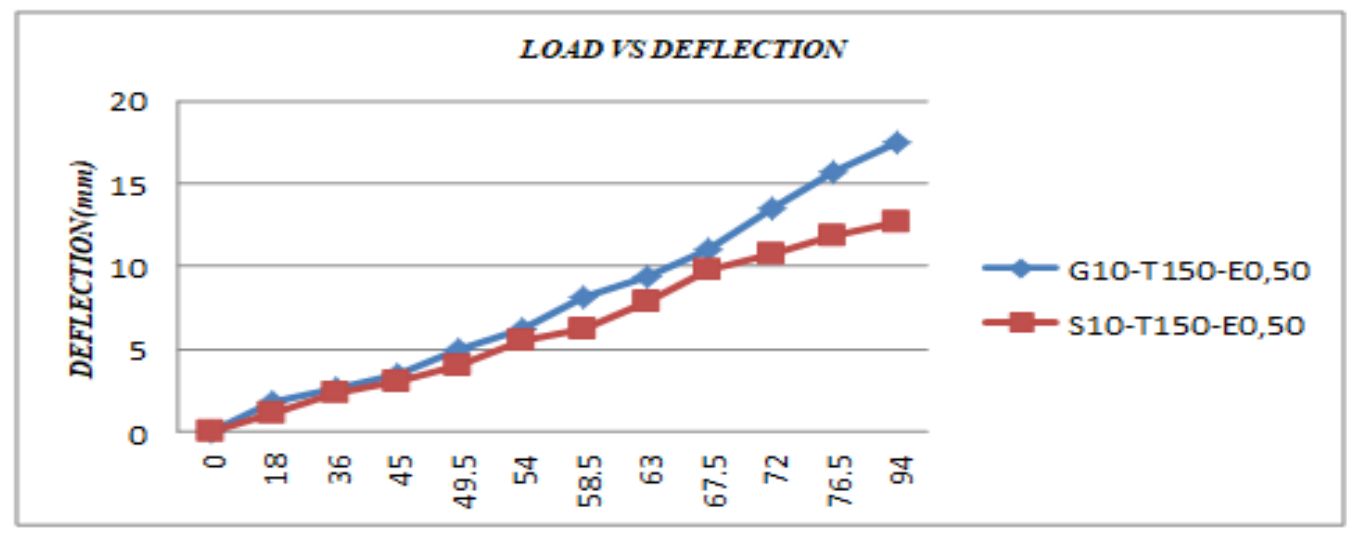

Fig: 23 Load vs Deflection - G10-T150-E0, 50 AND S10-T150-E0, 50

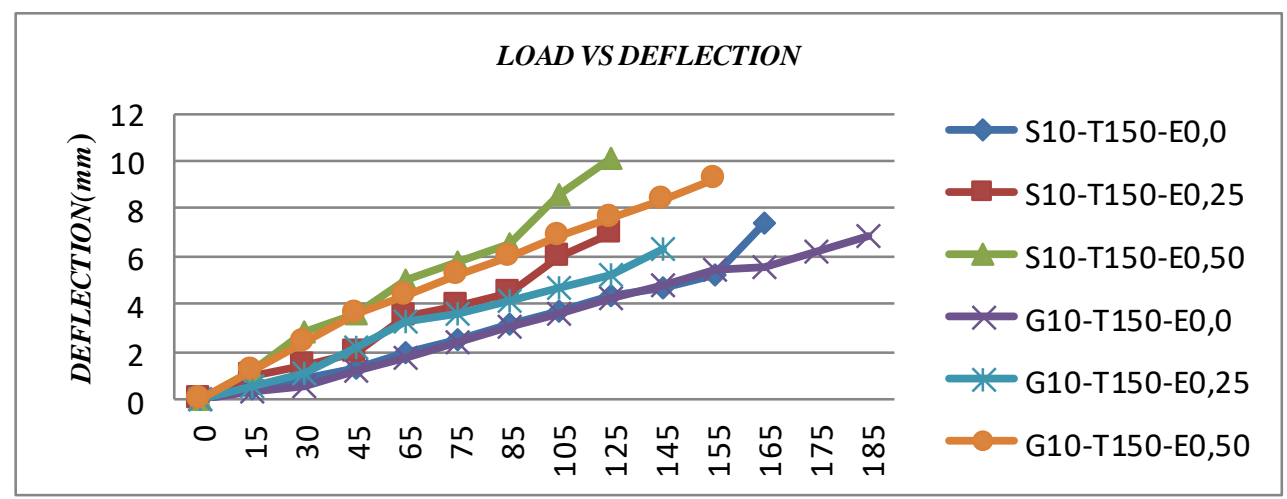

Fig: 24 Load vs Deflection hyfrc with gfrp - normal

\section{E. Stiffness}

Stiffness is the rigidity of an object - the extent to which it resists deformation in response to an applied force.

Stiffness is measured in force per unit length $(\mathrm{N} / \mathrm{mm})$, and is equivalent to the "force constant" in Hooke's Law.

Stiffness $\mathrm{K}=\mathrm{P} / \delta$

TABLE 12: INITIAL STIFFNESS AND FINAL STIFFNESS

\begin{tabular}{|c|c|c|c|c|}
\hline S.no & Specimen & $\begin{array}{c}\text { Initial stiffness } \\
(\mathbf{N} / \mathbf{m m})\end{array}$ & $\begin{array}{c}\text { Final stiffness } \\
(\mathrm{N} / \mathrm{mm})\end{array}$ & $\begin{array}{c}\text { Average } \\
{\mathrm{X} 10^{3} \mathrm{~N} / \mathrm{mm}}\end{array}$ \\
\hline 1. & S10-T150-E0,25 & 13.12 & 14.25 & 14.25 \\
\hline 2. & G10-T150-E0,25 & 12.41 & 11.05 & \multirow[t]{2}{*}{11.7} \\
\hline 3. & G10-T150-E0,25 & 11.5 & 12.35 & \\
\hline 4. & S10-T150-E0,50 & 7.25 & 7.58 & 7.58 \\
\hline 5. & G10-T150-E0,50 & 5.532 & 6.818 & \multirow[t]{2}{*}{5.884} \\
\hline 6. & G10-T150-E0,50 & 6.25 & 4.95 & \\
\hline
\end{tabular}

F. Crack pattern

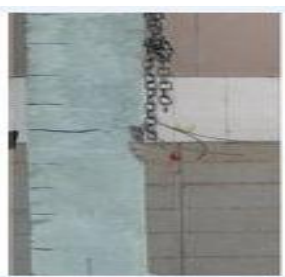

S10-T150-E0, 0

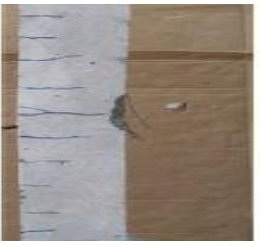

G10-T150-E0,0-1

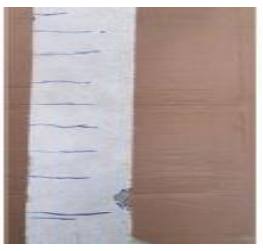

G10-T150-E0,25 -1

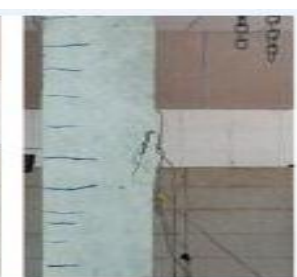

S10-T150-E0,25

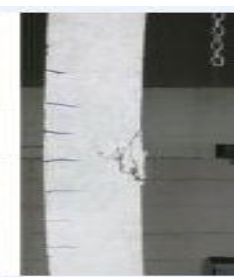

S10-T150-E0,50

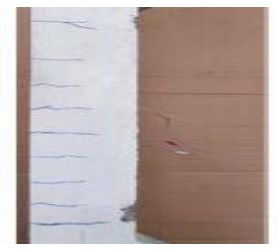

G10-T150-E0,50-1

Fig: 25 Ultimate load crack profile

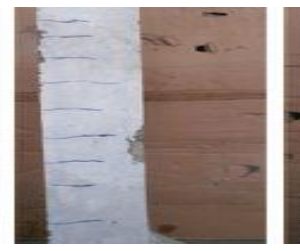

G10-T150-E0,0 -2

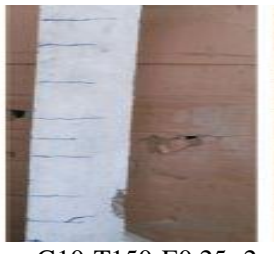

G10-T150-E0,25 -2

G10-T150-E0,50-2

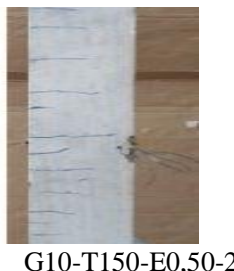




\section{V.CONCLUSION}

The following conclusions were drawn based on the experimental investigation on eccentric behavior of column

- The load carrying capacity of eccentricity $(0,0)$ HYFRC column with GFRP was found to be $18 \%$ greater than the value of conventional concrete column.

- The maximum deflection noted at their ultimate axial load in the GFRP rebar and normal steel reinforcement column are $1.45 \mathrm{~mm}$ and $1.3 \mathrm{~mm}$ respectively.

- Percentage of eccentricity increase in GFRP column is very similar to behaviour of conventional reinforced column

- All eccentric loaded GFRP columns showed no rebar failure and the column top compression zone crushing failure occurred.

- Hybrid fibre performed well with increase in compressive strength and prevention of fine cracks.

- The moment carrying capacity GFRP column was 5\% higher than the steel reinforcement column.

- The increase of eccentricity of GFRP column decreased the stiffness compare to axial stiffness

- The GFRP column with increase in the eccentricity without local buckling or elastic in stability

- GFRP column had large deflection capacity without failure compared to steel reinforcement column.

\section{REFERENCES}

[1] ACI 440.1R-06 Guide for the design and construction of structural concrete reinforcement with FRP bars .USA2015

[2] ACI319:1989 building code requirements for reinforced concrete, American concrete institute.

[3] Ahmed heidayet mohammed(2019), "behaviour of eccentric concrete column reinforced with carbon fibre reinforcement polymer bar, international journal of emerging trends of technology in computer science.

[4] Nandini devi and deepi (2017), "performance of concrete column with glass fibre reinforced polymer rebar under axial loading.

[5] IS456-2000, "plain and reinforced concrete code of practices" Indian standard.

[6] IS456-1978, "Design aids for reinforced concrete to sp16.

[7] AS3600:1988, "concrete structure, standards association of Australia.

[8] American concrete institute, ' 'building code requirements for structural concrete (ACI318-16), USA, 2014

[9] M.N.Sheikh, "Experimental investigation on circular concrete columns using GFRP bars and helices under different loading conditions" journal of composite for construction vol.20, No: 4, article 04016009:2016.

[10] B.Benmokrane, "strength of circular HSC columns reinforced internally with CFRP bars under axial and eccentric loadings," constructoin and building materials, vol.141, pp.336-378, 2017 